\title{
A border opening onto numerous geopolitical issues
}

The Yanbian Korean Autonomous Prefecture

Sébastien Colin

\section{OpenEdition}

\section{Journals}

Édition électronique

URL : http://journals.openedition.org/chinaperspectives/385

DOI : $10.4000 /$ chinaperspectives.385

ISSN : 1996-4617

Éditeur

Centre d'étude français sur la Chine contemporaine

Édition imprimée

Date de publication : 1 août 2003

ISSN : 2070-3449

\section{Référence électronique}

Sébastien Colin, «A border opening onto numerous geopolitical issues », China Perspectives [En ligne], 48 | july-august 2003, mis en ligne le 20 décembre 2006, consulté le 28 octobre 2019. URL : http:// journals.openedition.org/chinaperspectives/385 ; DOI : 10.4000/chinaperspectives.385

Ce document a été généré automatiquement le 28 octobre 2019

(c) All rights reserved 


\title{
A border opening onto numerous geopolitical issues
}

\author{
The Yanbian Korean Autonomous Prefecture
}

\section{Sébastien Colin}

\section{NOTE DE L'ÉDITEUR}

Translated from the French original by Philip Liddell

1 On September $3^{\text {rd }}$ 2002, the Yanbian Korean Autonomous Prefecture celebrated the fiftieth anniversary of its founding.

2 Yanbian is located in the province of Jilin; of China's thirty autonomous prefectures, it is the only one in the northeast (1). It is the largest administrative entity in the province, covering an area of 42,700 square kilometres; it is subdivided into six municipalities, Yanji, Longjing, Helong, Tumen, Dunhua and Hunchun, and two counties, Antu and Wangqing (see map). As the layout of the hydrographical network indicates, Yanbian is oriented towards China's frontier with North Korea and towards the sea. The landscape is dominated by an arc of wooded mountainside cut across with valleys that come together at the level of Yanji and Tumen and then merge into a vast plain around Hunchun. Most of its people and its cultivated land are naturally concentrated along these valleys and on the plain. Despite everything, the prefecture has two outstanding geographical features: its shared frontier with Russia and North Korea, and its ethnic composition, which, at about 840,000 people, has the highest concentration of Chinese Koreans (Chaoxianzu) ${ }^{1}$. On the scale of the prefecture itself, however, this ethnic Korean population is still in the minority: in 2000, it represented only $38.55 \%$ of Yanbian's 2,184,000 inhabitants, set against the $58.54 \%$ of Chinese Han. Lastly, the population is unevenly distributed: the administrative entities close to the frontier with North Korea have higher proportions of Koreans than those further away, where the Han are in the majority (see map and Table ${ }^{2}$ ). 
3 This distribution is historical in origin. Unlike many other mino rities, the ethnic Koreans came to Chinese territory as immigrants and not through territorial expansion ${ }^{3}$. Migrating to a region that was virtually free of human settlement in the second half of the nineteenth century, the Korean peasants were thus able to settle on the plains within reach of the border.

4 The festivities organised in commemoration of the anniversary gave the central, provincial and local authorities the opportunity to celebrate the characteristic features of Korean culture and to re-emphasise the importance of economic development to the prefecture ${ }^{4}$. The aim, as every September, was also to encourage harmonious relations between the various "nationalities" living within the prefecture ${ }^{5}$. Even though the festivities were longer and more spectacular, this celebration of the anniversary would hardly have differed from the annual rejoicing had it not been introduced by the sanguan jiaoyu campaign, organised by the provincial government, supported by the central government and aimed at the Korean minority. Its main objective was to remind people of the importance of unity between the "nationalities" in the successful pursuit of development ${ }^{6}$. The sanguan jiaoyu campaign (teaching the three principles governing relations between the minorities and the Han) demonstrates that the central government is keeping a careful eye on the behaviour of the Yanbian Koreans. Indeed, since the prefecture opened its frontiers to North Korea in the mid-1980s and South Korea in the early 1990s, the two neighbours are tending to pose new problems for the Chinese authorities.

The decision to open up Yanbian was made for two reasons. The first was a matter of foreign policy: Yanbian and the Korean minority were to be incorporated within China's new strategy towards the Korean peninsular, the objective of which is to encourage the reunification of the two Koreas. The second consideration was domestic: frontier security was to be assured by favouring the economic development of the prefecture. These two strategic concerns gave birth to an ambitious development policy in the first half of the 1990s. However, the consequences were not quite those anticipated. In fact, economic growth slowed during the second half of the 1990s, aggravating the economic and social unrest within the Korean population, among whom some individuals maintain relations with the two Koreas that have raised problems for the Chinese central government. Peking is embarrassed in particular by the many Chaoxianzu who have emigrated to South Korea and by the complicity of some in the smuggling of North Korean refugees into Peking and South Korea. These activities, which at the local level are possible causes of destabilisation, also raise diplomatic tensions between China and the two Koreas.

Faced with these new problems, the central government has recently been attempting to reinvigorate the development of Yanbian.

Opening up Yanbian at the end of the 1980s: what was at stake?From the founding of Yanbian to the opening up of the frontier: a historical reminder

In the beginning, Yanbian was a former clearance area that the Qing government created at the end of the nineteenth century to accommodate the many Korean peasants who were emigrating from the provinces in the northeast of Korea. Following this opening of the frontier, Japan's take-over of Korea, first as a protectorate in 1905 and then by annexation in 1910, led to new waves of Korean immigration into Yanbian. Between 1881 and 1931, the Korean population of Yanbian swelled from 10,000 to 
396,850 people. On the eve of the Japanese defeat, it had reached 635,000 people, which represented $74 \%$ of the total population ${ }^{7}$.

7 Yanbian was founded for reasons of foreign policy. The Qing rulers needed to respond both to the pressure of Han and Korean immigration and to the threats posed by Russia and Japan. In 1858 and 1860, two treaties were signed that drew the frontier between the Chinese and Russian empires: China lost an immense sweep of territory, including its access to the East Sea (Sea of Japan). The meeting point of the Russian, Korean and Chinese frontiers was then fixed on the northern bank of the Tumen river about 15 kilometres from the coast ${ }^{8}$. At the same time, Han and Korean peasants, from the Chinese provinces of Shandong and Hebei respectively, and from the northern provinces of Korea, began to settle illegally in the Yanbian region ${ }^{9}$. This illegal immigration into Chinese territory, on the fringes of Korea and Russia, greatly troubled the Qing court. Indeed, while it helped to populate the frontier regions, this immigration nevertheless had to be controlled, lest it be exploited by the Russians and the Japanese whose influence in Korea was growing ${ }^{10}$. Lastly, by welcoming the immigrants, China could show that it offered protection to the Korean population and could thus increase its influence in the domestic affairs of the peninsular, which the Korean authorities were finding increasingly hard to control, and fend off its Russian and Japanese enemies.

Table1: Han and Korean populations in Yanbian's municipalities and districts (2000)

\begin{tabular}{lrrr}
$\begin{array}{c}\text { Population } \\
(000)\end{array}$ & $\begin{array}{c}\text { Han } \\
(\%)\end{array}$ & $\begin{array}{r}\text { Koreans } \\
(\%)\end{array}$ \\
\hline Yanji & 389.19 & 58.64 \\
57.29 \\
Tumen
\end{tabular}

Source: Yanbian tongji nianjian 2001, Yanji, Yanbian renmin chubanshe, 2001, pp.67-68 and 73.

8 However, when Japan established its domination of Korea, at the start of the twentieth century, it took the large Korean population in the clearance area as a pretext for justifying new territorial ambitions. For Japan, these people, just like those on the peninsular, had to be afforded its "protection". The Korean population of Yanbian then became a real issue between the Chinese and Japanese authorities, with each government attempting to win its support ${ }^{11}$. Even though a section of the Yanbian Koreans aligned itself with Japan-which moved into Yanbian as early as 1907 and then into the rest of Manchuria in 1931-most of them joined the communist camp and struggled against the invader.

9 The large proportion of Korean people on the edge of the Chinese territory and the role the Koreans played in resisting not just the Japanese but also the Kuomintang regime, were the main reasons that qualified Yanbian for autonomous status. 


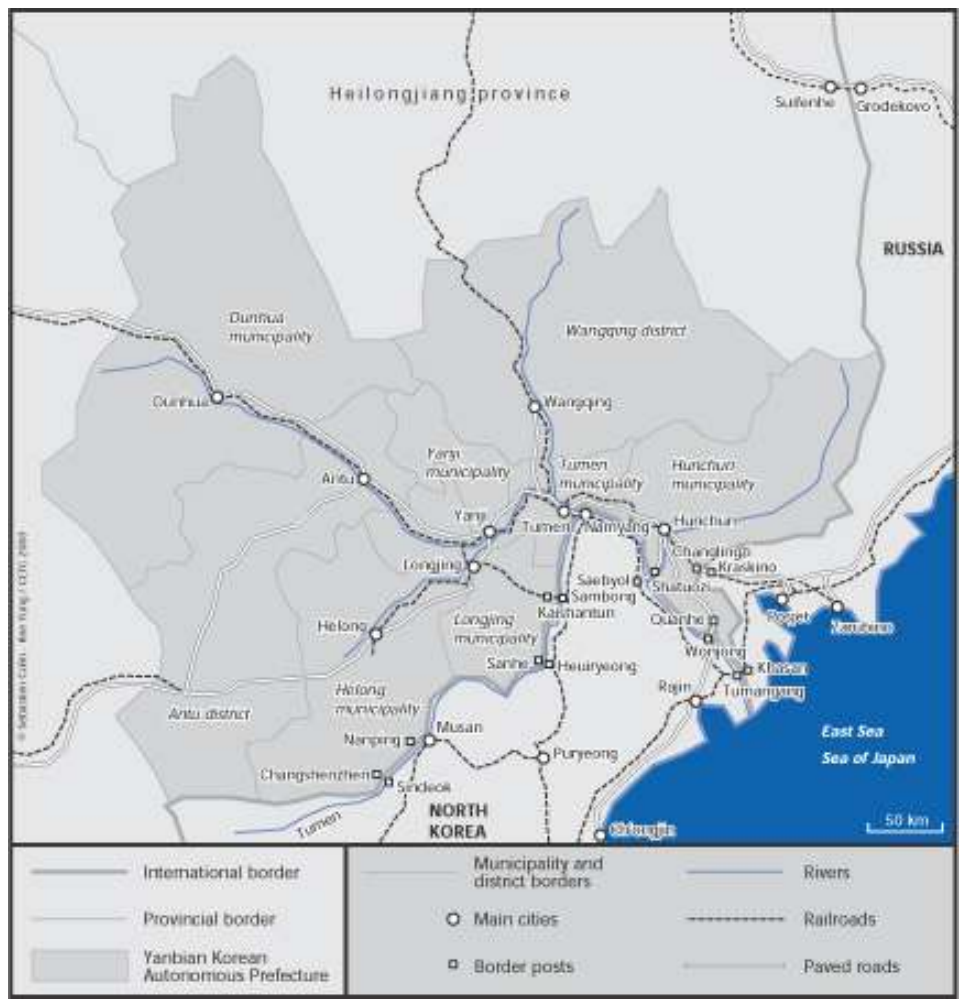

The "Yanbian Korean Autonomous Region" (Yanbian Chaoxianzu zizhiqu) was founded on 3 September 1952. However, despite its title of zizhiqu, a term also used to designate autonomous regions at the provincial level, Yanbian remained subordinate to the province of Jilin. After the 1954 Constitution was published, which converted autonomous regions under the jurisdiction of provinces (zizhiqu) into prefectures (zhou), the State Council officially promulgated in April 1955 the creation of the "Yanbian Korean Autonomous Prefecture" (Yanbian Chaoxianzu zizhizhou) ${ }^{12}$.

Between 1952 and 1957, regional autonomy was put into genuine practice in Yanbian. The Korean minority was strongly represented in the various authorities of the Chinese Communist Party (CCP) and local government, and the Autonomous Prefecture was considered by the central government to be a "model of autonomy". It was the most advanced autonomous administrative entity in China: in fact, the standard of living enjoyed by the Koreans and their levels of education were even higher than those of the Han. The autonomy granted to Yanbian did not, unfortunately, last for long. The Great Leap Forward and the Cultural Revolution witnessed the imposition of an assimilation policy. The prefecture's shared frontiers with the Soviet Union and North Korea added greater intensity to these campaigns of repression. The Sino-Soviet schism of 1959 and the ups and downs that affected China's relations with North Korea between 1958 and 1970 made Yanbian a very sensitive region. During the Cultural Revolution, Yanbian even became totally militarised, dominated by the People's Liberation Army, with Mao Yuanxin, Mao Zedong's own nephew ${ }^{13}$ at its head.

It was not until Deng Xiaoping had come to power, and not until the 1982 Constitution and the May 1984 "Law on the Autonomy of Regional Nationalities" had both been promulgated, that policy towards the national minorities was to become more lenient and that the term "regional autonomy" came to mean something again. 
13 In Yanbian, this revival took concrete form in 1985 with the promulgation of regulations laying down the law on the autonomy of the prefecture (Yanbian Chaoxianzu zizhizhou zizhi tiaoli) and the representation of Koreans in local political and administrative bodies. A year later, the prefecture authorities published three other regulations on the use of the Korean language, the development of traditional Chaoxianzu culture and the production of traditional Korean products; the regulations also set up a body responsible for promoting economic and cultural exchanges with foreign countries (haiwai lianyi hui). In all, more than 70 regulations were implemented between 1985 and 1988, concerning, among other things, agriculture, forestry, science, education, health, family planning, taxation and commerce ${ }^{14}$.

These reforms followed the visit to Yanbian in 1983 by Deng Xiaoping, during which he declared himself in favour of "a swift and improved building up of the Yanbian Korean Autonomous Prefecture" (ba Yanbian Chaoxianzu zizhizhou jianshe de geng kuai xie geng hao xie), thus marking the first stage towards opening up the prefecture's frontier with the outside world ${ }^{15}$.

The strategic motivation behind the opening up of the frontier

The Great Leap Forward and the Cultural Revolution had left the Party's credibility greatly diminished and had poisoned relationships between the Koreans and the Han. Deng's visit and the renewal of economic development were a means for the Party to win back the confidence of the Yanbian Koreans. This new attitude had a further aim: Peking's new policy towards the Korean peninsular might profit from the co-operation of China's Chaoxianzu ${ }^{16}$.

Firstly, the central government needed to revive its relations with North Korea's leaders. Indeed, the normalisation of China's diplomatic relations with Japan and then the United States during the 1970s as well as the opening up of the market economy in 1978 were sharply criticised by North Korea, which then tightened its links with the USSR. Secondly, the government wished to restore its position at the centre of Northeast Asia, not only by rebuilding its relationship with the Soviet Union (and later Russia) but also by acting as go-between in bringing the two Koreas together. To that end, the Chinese government had to opt for normalising its relations with the south while taking care not to put a strain on its links with the north. The closeness of these links was proving all the more important in that the appearance of serious economic difficulties might threaten the survival of the North Korean regime, which might in turn leave the Chinese government fearful for the stability of its frontier.

17 In order to confront these numerous issues, from the end of the 1980s, the central government allied itself with provincial and local initiatives to implement a new economic policy, symbolised by the Tumen River Area Development Programme. This programme was designed, among other objectives, to promote the economic development of Yanbian, to offer the prefecture access to South Korea and to help launch North Korea along the path of reform ${ }^{17}$. The policy satisfied a national need by enabling China to narrow the currently growing gap between Yanbian's slow economic development and the rapid advances being made in the coastal provinces, a gap that might feed local discontent in Yanbian and also threaten the stability of the frontier ${ }^{18}$.

Thus, when Jiang Zemin, then Secretary General of the Party, visited Yanbian between 7 and 9 January 1991, he proclaimed the central government's wish to make Yanbian a "model prefecture" for the whole country. He encouraged the local authorities to parade the various advantages that the prefecture enjoyed, such as its "ideal 
geographical position" on the frontiers of Russia and North Korea and in the centre of Northeast Asia, its rich natural resources (such as wood and medicinal plants) and its picturesque landscape (mainly with tourism in mind) ${ }^{19}$. He repeatedly encouraged the local authorities to continue exploiting the ethnic network of the Korean population so as to form closer economic and trading links with the two Koreas ${ }^{20}$.

The openness strategy of the 1990s and its problemsThe launch of the Tumen project The start of the reforms took the form of reopening the frontier with North Korea, which had been closed since the start of the Cultural Revolution. First of all, the Chinese and North Korean authorities established relations between localities $\left({ }^{21}\right)$, and then they reactivated treaties signed during the 1950s and the early 1960s, among them an agreement on cross-border movement ${ }^{22}$. Trade was also built up, reaching a value of 52 million dollars by $1989^{23}$. This reopening was encouraged by an important political act, the visit to Yanbian in 1984 of Hu Yaobang, then Secretary General of the CCP, and Kim Il-Sung, whose regime promulgated in September of that year a law allowing foreign investment.

However, some local and provincial leaders judged this reopening to be economically inadequate. In their view, these two administrative entities of Northeast China were lagging behind the coastal provinces in development because the region was isolated, having been cut off from access to the East Sea (Sea of Japan) since the latter half of the nineteenth century. This is when the idea of establishing an economic zone around the meeting point of the Chinese, Russian and North Korean frontiers, with the financial support of Japan, South Korea and the United Nations Development Programme (UNDP), was first mooted. This local project, which was called, symbolically, the Tumen River Economic Development Zone, was aimed at renovating existing infrastructure and building new projects to improve transport (roads, railways, port installations and frontier posts) so as to regain access to the sea by using the Russian ports of Zarubino and Posjet and the North Korean ports of Rajin and Chongjin.

Table 2: Main foreign investments in Yanbian since the opening of the border in June 2002.

\begin{tabular}{|c|c|c|}
\hline $\begin{array}{l}\text { Origin of the } \\
\text { investments }\end{array}$ & $\begin{array}{l}\text { Volume of investments } \\
\text { (million of USS) }\end{array}$ & $\begin{array}{l}\text { Number of } \\
\text { companies }\end{array}$ \\
\hline South Korea & $356.61 \mathrm{E}$ & 463 \\
\hline Hong Kong & $132.92 \square$ & 46 ㄹ. \\
\hline Japan & $50.11 \mathrm{E}$ & 47 . \\
\hline United Kingdom & 29.5 ] & 1 \\
\hline Taiwan & 22.65 I & 22 \\
\hline Bermuda & 5.63 & 1 \\
\hline United States & 5.53 & 181 \\
\hline Indonesia & 5.43 & 11 \\
\hline Sweden & 4.7 & 21 \\
\hline North Korea & 2.63 & 141 \\
\hline $\begin{array}{l}\text { Investments } \\
\text { in total }\end{array}$ & 615.71 & 615 \\
\hline
\end{tabular}

Source: Yanbian chaoxianzu zizhizhou duiwai jingji maoyi ding (The foreign economy and foreign trade office of the yanbian Korean Autonomous Prefecture), summer 2002.

During the first half of the 1990s, the central government took an active part in the financing of the infrastructure. With its international objectives in mind, it gave strong encouragement to the local authorities to attract investment from abroad by creating, 
in Hunchun in March 1992, a frontier zone of economic co-operation (bianjing jingji hezuoqu), a project driven directly from Peking; and it gave the go-ahead to the Jilin authorities for several economic development zones at the provincial level across the rest of the prefecture ${ }^{24}$. In addition, the central government played a key role in encouraging the North Korean authorities to set up the economic zone of RajinSonbong in 1991 and in persuading them not to leave the Tumen programme when they threatened to do so at the time of the first nuclear crisis in 1994. It was also a Chinese company in Yanbian, the Xiantong Haiyun Jituan Youxian Gongsi that, as the only company using the port of Rajin, was largely responsible for its renovation, relieving the failing North Korea of this task ${ }^{25}$.

While the Tumen programme did, of course, help to open up Yanbian, the economic results of the decade as a whole remained disappointing. Even today, numerous problems remain.

Persistent economic difficulties

The economy of Yanbian experienced a sharp slowdown during the second half of the 1990s. Its falling ranking among China's 30 autonomous prefectures perfectly illustrates this decline. From being the most developed of the autonomous prefectures in 1990, by 1995 Yanbian had slipped to second place and by 2000 to fifth place. In 1995, the value of its industrial production was 94 billion yuan, which was 38 billion less than the most developed of its rivals, the autonomous prefecture of the Kazakhs of Yili in the autonomous region of Xinjiang. In 1999, not only had the gap between Yanbian and Yili widened-from 38 billion to 62 billion yuan-but by that year Yanbian had also been overtaken by three other autonomous prefectures, those of the Yi of Liangshan in Sichuan province, the Hani and Yi of Honghe in Yunnan province, and lastly the Bai of Dali, also in Yunnan ${ }^{26}$.

The prefecture of the Yanbian Koreans remains poor in terms of foreign investment. Between the end of the 1980s and June 2002, it attracted only 615 enterprises, worth a total of 615 million dollars (see Table 2) ${ }^{27}$. Despite the new fiscal policies implemented during the first half of the 1990s, taxes are still considered too onerous and too numerous. Yanbian's workforce suffers from a cruel lack of skills in key sectors such as the environment, foreign languages and new technologies ${ }^{28}$. While the presence of the Korean minority has helped to attract a large number of Korean businesses, these are only small and medium-sized enterprises profiting from cheap labour. The big South Korean groups invest elsewhere, mainly in the provinces of Liaoning and Shandong. The ethnic network is in fact much more beneficial to the individual and to the family economy: members of the Korean minority use it primarily to go and work in South Korea and to trade with Koreans on the peninsular or with foreigners of Korean origin 29. Lastly, the industrial structure of the prefecture is still overly dominated by state enterprises whose technology dates back to the 1950s, the 1960s and the 1970s; it does not boast enough enterprises capable of offering products with a high added value. The proportion of such products within overall industrial production is the smallest to be found anywhere in Jilin province ${ }^{30}$. 
Table 3: Volume of foreign trade of the Yanbian prefecture (US\$'000)

\begin{tabular}{|c|c|c|c|c|c|c|c|}
\hline & & North Kores & Russia & South $\mathrm{K}$ & tarea & Iepan & \\
\hline & imports & 36690 므 & 204800 & 220 & 1 & & \\
\hline 1991 & Exports & 37,860 므 & 169101 & 4.640 & 1 & 2.530 & 1 \\
\hline & Total & $74,540 \mathrm{D}$ & 37,390 E & 4850 & ! & & \\
\hline & mports & 83,940 & $53,600 \square$ & 1.500 & I & & \\
\hline 1992 & Exports & $61.500 \square$ & $56600 \square$ & 5.880 & 5 & 3.300 & g \\
\hline & Total & 145920 를 & 120,290 & 6.660 & I & & \\
\hline & imports & 162,600 & $73,020 \square$ & 1,870 & 1 & & \\
\hline 1993 & Exports & 144,690 트 & 62.280 $\square$ & 4,900 & 1 & 4,430 & 1] \\
\hline & Total & 177,320 E & 135,270 & 6.770 & $t$ & & \\
\hline & mpots & 112.230 & $64,870 \square$ & 19,460 & E & 8.100 & I \\
\hline 1994 & Exports & 113,710 & $51,730 \square$ & 13.900 & (1) & 13,470 & I \\
\hline & Total & $225,940 \mathrm{E}$ & 116,600 & 37,360 & ㅁ & 21,650 & E \\
\hline & mports & 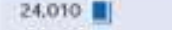 & 6.530 ] & 30030 & 를 & 7.670 & I \\
\hline 1996 & Exports & 30,350 E & 4.8201 & 29060 & 붕 & 17,550 & 1 \\
\hline & Total & $54,360 \mathrm{E}$ & 11,350 ] & 59,090 & $E$ & 262200 & ㅍ \\
\hline & inports & 8,3401 & $10.850 \mathrm{I}$ & 63.530 & E & A, 4 ED & 1 \\
\hline 1996 & Exports & 13,540 I & 2.540 i] & 32.370 & 르 & 19, во & (1) \\
\hline & Total & 22,180 E & $13,390 \mathrm{I}$ & 96,100 & E & 28,350 & 므 \\
\hline & inports & 13,010 I] & 3270 ] & 26.370 & 를 & 22,040 & 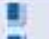 \\
\hline 1997 & Exports & $24,340 \mathrm{E}$ & 2,760 i] & 49000 & ㄹ & 24.560 & ㅁ] \\
\hline & Total & 35,350 브 & 60301 & 74370 & 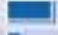 & 46,600 & 피 \\
\hline & inports & 88501 & 13,880 I & 20,570 & 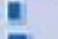 & 7,300 & 1 \\
\hline 1998 & Exports & $21,720=$ & 2760 if & 33270 & 目 & 24,660 & ㅁ] \\
\hline & Total & 30,570 르 & $14,640 \mathrm{I}$ & 53,940 & $\square$ & 31,960 & 트 \\
\hline & Imports & $2.820 \mathrm{U}$ & 45,620 & 27,420 & 들 & 11,600 & 1 \\
\hline 1998 & Exports & $40.910 \mathrm{E}$ & 3,9601 & 45,520 & ㅁ & 37.830 & 미 \\
\hline & Total & $50,730 \square$ & $49,650 \square$ & 74.040 & 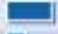 & 49,430 & 미 \\
\hline & Inpoets & 8.480 I & $42,120=$ & 26,710 & 흐 & 10,680 & I \\
\hline 2000 & Exports & 40440 要 & 2.890 if & 55,470 & $\Xi$ & 50,410 & 모 \\
\hline & Total & 48,920 & $50,010 \mathrm{D}$ & 82,180 & E & 61,090 & $\Xi$ \\
\hline
\end{tabular}

Source: Yanbian chaoxianzu zizhizhou duiwai jingji maoyi ding (The foreign economy and foreign trade office of the yanbian Korean Autonomous Prefecture), summer 2002.

Yanbian's low level of economic dynamism is also evident in its external trade. Admittedly, the level did rise between 1991 and 2000, but its progress was very uneven (see Table 3). Russia and North Korea, Yanbian's main trading partners at the start of the 1990s, were overtaken by South Korea and Japan as a result of the collapse of China's trade with Russia and North Korea in the mid 1990s. Each of these partners represented trade worth 50 million dollars by 2000, and although these figures have certainly increased since, the value is still inadequate ${ }^{31}$. A large share of the crossborder trade is accounted for by private companies (minying qiye) which take advantage of the existing markets at each of the prefecture's frontier posts to sell, buy or exchange ${ }^{32}$. However, most of the trade flowing between China and Russia and between China and North Korea bypasses Yanbian. National trading between China and Russia flows more to the north, through the province of Heilongjiang, and trade between China and North Korea uses the frontier crossings further to the south in the province of Liaoning ${ }^{33}$. So the isolation of the prefecture is still a reality. Moreover, the main trade routes between Yanbian and South Korea and between Yanbian and Japan-which remain modest despite, admittedly, experiencing steady growth-go through the port of Dalian, neglecting the ports in the Tumen zone even though they are much closer.

Why the impetus has been lost

The economic difficulties of Yanbian find their explanation in the numerous obstacles that the Tumen programme has encountered-and continues to encounter ${ }^{34}$.

Because of the inadequate transport and port infrastructure, access to the sea-which was, after all, the initial aim of the project-is still not completely operational. The investment needed is lacking; the failure to complete the infrastructure is a handicap 
to trade and puts off foreign investors. State investment by the Chinese central authorities also dwindled in the second half of the $1990 \mathrm{~s}^{35}$. There are two main reasons for this reduction. As a programme for cross-border co-operation, the Tumen programme cannot succeed without the active participation of the Russian and North Korean partners. Yet the considerable political reluctance of the local Russian authorities in Primorskiy and of the North Korean government has contributed strongly to slowing down the project. Moreover, the nuclear crisis of 1994 and the death of Kim Il-Sung strained relations between Pyongyang and Peking. At the same time, the launch of the Ninth Five-Year Plan (1996-2000) turned Peking's attention towards the development of China's central and western provinces, which largely explains the stronger economic growth achieved in the autonomous prefectures of these regions.

Within the prefecture, the Tumen programme has also been paralysed by the numerous tensions that it has itself created between Yanbian's main centres. Indeed, the lion's share of the profit has gone to the frontier municipality of Hunchun, which received the majority of the investments from Peking, while the railway connecting Yanji to North Korea via Longjing was renovated only with the help of local funding. This unequal treatment, deliberate on the part of the central government, has had the effect of sowing discontent among the areas that believe they have lost out in the unfolding of the programme (including Yanji, Longjing and Helong) ${ }^{36}$.

While the implementation of the Tumen programme has enabled the central government to use Yanbian and its Korean minority to further its strategy aimed at the two Koreas, active Korean participation also appears essential for the successful economic development of this prefecture. Yet North Korean reluctance and the overly timid economic participation of South Korean investors have combined to damage it fatally. The absence of economic prospects for Yanbian in the context of the opening up of the frontier has a number of consequences for the Korean minority, which is, in turn, causing problems, diplomatic ones in particular, for the Chinese authorities.

The consequences for the Korean minority of opening up the frontier

Opening up Yanbian to Korean influence from the mid-1980s onwards seemed a gamble on frontier stability. While it was necessary, from the point of view of the central government, to confront problems both within and without China, it also demonstrated the trust placed in the Korean minority. Because the Chaoxianzu were strongly politicised and relatively faithful to the CCP, the central government then qualified them as "a model minority", and they considered themselves as Chinese people of Korean origin. This double identity, which is common among immigrant populations, was reinforced by the important political role that the Korean minority had played in the history of the People's Republic as well as by the different policies that the central government directed towards it ${ }^{37}$. So, just as it had done in the past, the central government again played on the double identity of the Chaoxianzu in the early 1980s in the hope that they would play a positive role in reconciling the two Koreas. Here again, however, the outcome fell far short of the intention.

An economic and social malaise driving people to emigrate

31 The economic slowdown in the second half of the 1980s particularly affected the Korean minority. In Yanbian, Koreans were mainly employed in producing rice, fruit (primarily apples) and tobacco, and they suffered the full force of the competition whipped up by the reform policy ${ }^{38}$. Unlike the Han, they would not, or could not, adapt 
39. The impact was immediate. The Koreans saw their incomes drop and the gap widen between them and the Han. While the situation in the towns is relieved by the employment of some Koreans in foreign trade and by the availability of work in South Korea, many Koreans are still wretchedly poor ${ }^{40}$. These social problems have driven ever more Koreans to emigrate from Yanbian, a process that began from the moment the frontier was opened.

The Yanbian Koreans have migrated in the following three ways, though not necessarily in this order ${ }^{41}$. First there was the rural exodus. Hard hit by the reforms, many Korean peasants fled the countryside to the prefecture's main urban centres. In 2000 , the three municipalities of Yanji, Hunchun and Dunhua, the location of the urban centres of the same name that have profited most by development, were the only administrative entities to record a positive migratory balance, unlike the municipalities of Longjing, Helong and Tumen, to which rural Koreans have flocked in great numbers (see Table 4). When they do not go to the main urban centres within the prefecture, the Koreans flee Yanbian for the great developed cities of China where economic prospects are best. As well as Peking and the four great cities of the northeast (Harbin, Changchun, Shenyang and Dalian), migrants favour the Shandong municipalities (such as Jinan, Qingdao and Yantai) and those of the other coastal provinces. Lastly, the opening of the Yanbian frontier has offered new prospects for immigration. At first, the Yanbian Koreans made their way to North Korea and the Soviet Union, but the economic difficulties of these countries brought such population movements rapidly to an end. Salvation came in the renewal of trading relations between China and South Korea at the end of the 1980s and then in the normalisation of diplomatic links in 1992. South Korea has since become a real El Dorado, and it is to here that many Koreans from Yanbian and elsewhere in China attempt legally or illegally to migrate, mainly to work. According to some estimates, Chinese Koreans there numbered 23,000 in 1992 and over 40,000 by $1994^{42}$. By spring 2000, 92,000 were officially registered by the South Korean authorities but, according to some estimates that included illegal immigrants, their number had risen to 150,000 or 200,000 , which is more than half the immigrant workforce settled in South Korea ${ }^{43}$. While it is difficult to estimate the exact proportion of those who came from Yanbian, there is no doubt that it is significant. Indeed, since the frontiers opened, about 200,000 Yanbian Koreans have gone abroad ${ }^{44}$.

At the same time, and partly linked to this emigration, a slowdown has been recorded since the early 1990s in the growth of the Yanbian Korean population. Caused by a significant fall in the birth rate, population growth even became negative in the second half of the 1990s (see Table 5). The fall in the birth rate is largely explained by the malefemale imbalance in the countryside over several previous years; as a result of the high level of female emigration, this imbalance became particularly apparent during the 1990s. Today, the figures indicate that there are four men for every woman in the Yanbian countryside ${ }^{45}$. 
Table 4: Demographic dynamics of the population of Yanbian, by district and municipality (2000)

\begin{tabular}{|c|c|c|c|c|c|}
\hline & $\begin{array}{l}\text { Natural } \\
\text { grownth rate }\end{array}$ & $\begin{array}{l}\text { Crude birth } \\
\text { rate }\left(\Psi_{0}\right)\end{array}$ & $\begin{array}{l}\text { Crude death } \\
\text { rate }\left(\%_{0}\right)\end{array}$ & $\begin{array}{l}\text { Net migration } \\
\text { rate }\end{array}$ & $\begin{array}{l}\text { Growth } \\
\text { rate }\end{array}$ \\
\hline Yanji & 2.89 툴 & 8.54 & 5.65 & 9.35 & 8.96 \\
\hline Tumen & -3.59 口 & 5.66 & $9.25 \mathrm{E}$ & -151 & -6.07 \\
\hline Dunhua & $4.48 \mathrm{E}$ & 11.94 & 7,46 & 0.621 & 5.13 \\
\hline Hunchun & 0.481 & 7.39 & 6.91 & 8.07 & 8,05 \\
\hline Longjing & -4.29 国 & $5.16 \square$ & 9.45 & $\cdot 3.45$ & -7.06 \\
\hline Helong & -3.01 틀 & 5.64 & 8.65 & +4.75 & -7.07 \\
\hline Wangqing & -0.411 & $4,48 \square$ & 4.89 & -3.22 & -7.31 \\
\hline Antu & 2.89 듬 & 10.03 & 7.14 & -14.62 & -11.91 \\
\hline Yanbian & 1.021 & 8.23 & 7.21 & -248 & -0.501 \\
\hline
\end{tabular}

Source: Yanbian tongji nianjian 2001, Yanji, Yanbian renmin chubanshe, 2001, p.70

Table 5 : Characteristics of the Korean population of Yanbian between 1990 and 1999

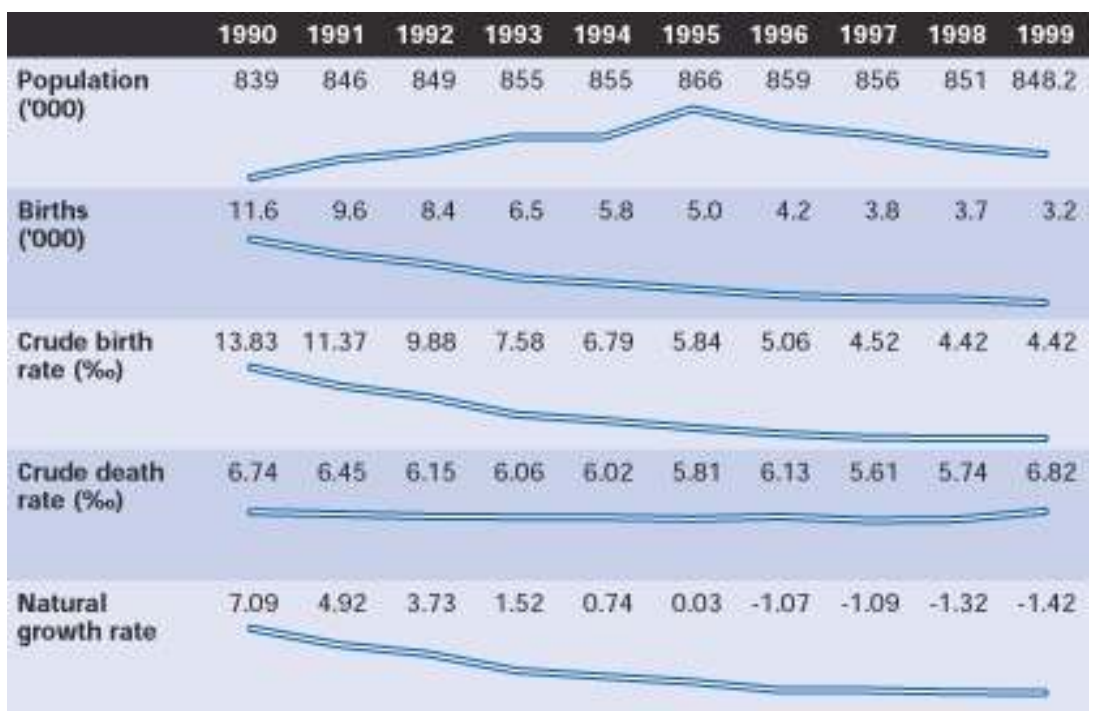

Source : Ryang Ok-Gûm, 'Jungguk yônbyôn josônjok jach'iju minjok gwangye ûi hyôngsông gwa baljôn'(Formation et d éveloppement des relations entre nationalités dans la préfecture autonome des Coréens de Yanbian), in Kim Kang-II éd., Jungguk josônjok sahwoeûi munhwausewa baljôn jônryak (Stratégie de développement et valeurs culturelles de la société chaoxianzu de Chine), yanji, Yônbyôn inmin ch'ulbansa, 2001, p.158.

The influence of the Chaoxianzu in Korean affairs

Economically limited, the main influence of the Chaoxianzu in Korean affairs is social and humanitarian. Particularly striking is the help they give to North Korean refugees.

The number of North Korean refugees now living in Yanbian is difficult to estimate. This is a sensitive subject; and, because the movements of refugees are fluid, any census is almost impossible. The few available figures concern the number of refugees in China and are unhelpful, varying between 10,000 and 300,000 according to different estimates ${ }^{46}$. Despite these variations, the Yanbian prefecture still seems to shelter the great majority of the refugees present on Chinese soil. The flow of refugees into Yanbian, which was very significant between 1998 and 2001, largely dried up during 2002. Alongside the various campaigns of repression, the renewal of frontier trade also appears responsible for this fall ${ }^{47}$. Trade between the frontier towns of Yanbian and their North Korean neighbours, mainly stimulated by the Chaoxianzu, thus saves a few North Koreans from having to flee into China to survive. 

and South Koreans ${ }^{49}$. birth rate ${ }^{53}$. verge of disintegration ${ }^{55}$.

When they do arrive in Yanbian, the North Koreans are often helped by the Chaoxianzu. While it is much too dangerous for the latter to welcome the refugees into their homes -and this is true even if they are members of their family-they attempt to help them by providing food or finding jobs for them in farming or forestry. Lastly, the bolder spirits help the refugees to flee to South Korea via a third country (such as Mongolia or Thailand) or via one of the many foreign embassies based in Peking.

This solidarity is not systematic, however. Some refugees are, on the contrary, subject to the arbitrary control of the local people or to organised crime networks. Of these, women are in the front line. According to some studies, $70-75 \%$ of the North Korean refugees in China are women and, of these, about $60 \%$ settle in Yanbian. This female surplus is exacerbated by the male-female imbalance in country areas of the prefecture. A large number of marriages are arranged between single rural Chaoxianzu men and women refugees from North Korea ${ }^{48}$.

Lastly, because the Chaoxianzu are able to move freely into each of the two Koreas, they frequently act as go-betweens in arranging meetings or carry letters between North

The "de-Koreanisation" of Yanbian and the question of Korean identity

Emigration and the slowdown in population growth have the combined effect of reducing the proportion of Yanbian Koreans within the wider community of Chinese Koreans. Whereas, in 1949, the Yanbian prefecture sheltered more than $60 \%$ of China's Koreans, today that proportion has fallen to $40 \%$ (see Table 6). In the longer term, this phenomenon raises the question of Korean representation within the governing bodies of the autonomous prefecture ${ }^{50}$. Indeed, according to the 1982 law, the proportion of officials drawn from a minority community in local political and administrative bodies must reflect its share of the overall population of the autonomous area. Thus, between 1952 and 2001, in parallel with the relative fall in the numbers of Koreans in Yanbian's total population, the proportion of Korean officials has dropped from $78 \%$ to $43.1 \%{ }^{51}$. Admittedly, the Chinese authorities have guaranteed that national minorities should fill the senior posts in the autonomous areas and that their share of officials should always remain above their share of the total population (52); but how will things turn out? At the local level, this imbalance is perceived as a serious problem, and to address it the prefecture authorities have been attempting for some time to encourage a higher

The depopulation of Yanbian also threatens the Korean identity of the Chaoxianzu. Their departure from Yanbian to settle in other towns means that many schools are forced to close down, but similar schools are not necessarily available at their new homes. Thus they are increasingly being assimilated within Chinese Han society ${ }^{54}$. Still worse, according to many Korean intellectuals, the Korean minority is at present on the

Such disintegration is all the more critical because opening up Yanbian to Korean influences has not strengthened the Korean identity of the Chaoxianzu. On the contrary, the Chaoxianzu have become so disillusioned in rediscovering the two Koreas that their Chinese patriotism has only intensified.

Chinese Koreans, for so long attached to North Korea, which they consider their country of origin, have been badly disappointed by political and economic developments in their motherland. The personality cult of the supreme leader, the 
emergence of a Kim dynasty, the Juche ideology, the total absence of individual freedom and the plight of refugees are elements of which they are sharply critical ${ }^{56}$. Only family ties still connect them with North Korea, which they hope will soon be opened up economically.

Most of the Chinese Koreans who have been to South Korea have also been badly disappointed. Their excitement at visiting this country and their chance to savour its high level of economic development have been soured by the discovery of a culture and a social existence that was quite different from theirs and to which they were unable to adapt ${ }^{57}$. What is worse, confronted daily by discriminatory laws, they have not found themselves treated as real Koreans. By limiting their freedom to settle down and by making their lives difficult, these laws create a persistently negative image of South Korea among the Chaoxianzu, many of whom return to China determined never to repeat the experience ${ }^{58}$.

The numerous contacts that they have had with the two Koreas have therefore consolidated the double identity of the Chinese Koreans. They have today a much more pragmatic vision of the peninsular, considering it merely as an important economic and political partner. As citizens, first and foremost, of the People's Republic, the Yanbian Koreans do not represent a real threat to the stability of the Sino-Korean frontier ${ }^{59}$. During the 1980s and 1990s, the Yanbian Korean Autonomous Prefecture was described several times by Peking and by the Jilin provincial authorities as the "model collectivity" (mofan jiti), meaning that the union between the nationalities there was judged to be satisfactory ${ }^{60}$. Nevertheless, other sources have qualified this idealised view. They consider that the Korean minority is an intermediate nationality, "neither cold nor hot" (bu leng bu re); it is not inclined to separatism, as is the case with national minorities in Tibet and Xinjiang, but neither is it "without risk to the social and political stability of the region", particularly because of the relations it maintains with some citizens of the two Koreas ${ }^{61}$.

This ambivalent situation, which varies from person to person, obliges the central government to be wary of the Chaoxianzu, especially when they cause problems for its diplomatic relations with the two Koreas.

The problems caused by the Yanbian Chaoxianzu to China's relations with Korea

The migration of Chinese Koreans to South Korea and the support they offer to North Korean refugees are frequently the cause of diplomatic clashes between China and the two Korean states. These problems are all the more embarrassing in that a significant criminal factor is involved. 
Table 6: Proportion of Koreans from Yanbian in the whole Korean population of China

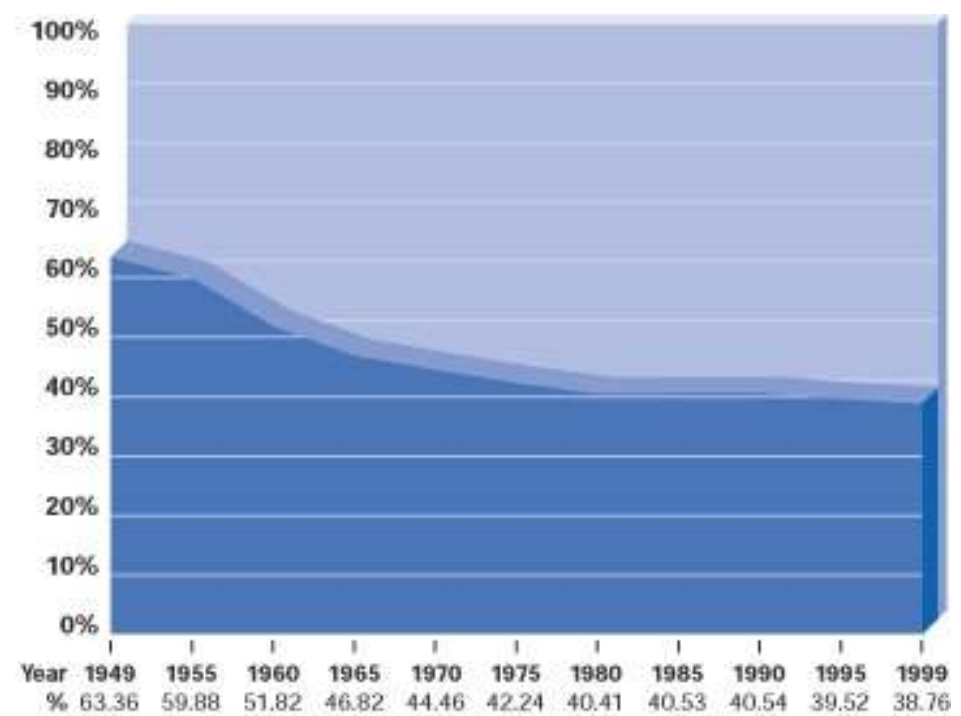

Source : Ryang Ok-Gûm, 'Jungguk yônbyôn josônjok jach'iju minjok gwangye ûi hyôngsông gwa baljôn'(Formation et d éveloppement des relations entre nationalités dans la préfecture autonome des Coréens de Yanbian), in Kim Kang-II éd., Jungguk josônjok..., op.cit., p. 158.

The political issues raised by Chaoxianzu immigration in South Korea

The central government in China, fearful that South Korea might win too much influence over China's Korean community, keeps a close eye on South Korean immigration policy. Moreover, Seoul did not fail to make use of its influence when it published its law concerning the legal status of Koreans from abroad. Coming into force on 12 August 1999, this law authorised foreigners of Korean origin to reside in South Korea without a visa for one or two years, which made it easy for them to look for work. However, in common with Koreans in Russia, those in China were not affected by this law. Indeed, the South Korean authorities accept as Koreans from abroad only those persons (or descendants of persons) who left South Korea after 1948, thus excluding those who were forced to leave the peninsular at the end of the nineteenth century or during the Japanese occupation ${ }^{62}$. While it helped to avoid any friction with the Chinese government, this exclusion provoked uproar among the immigrant Chaoxianzu population and also among South Korean Non-Governmental Organisations (NGOs), who organised numerous demonstrations in Seoul and sent a petition to the country's Constitutional Court. This pressure from part of society obliged the central government to think again. On 31 August 1999, President Kim Dae-Jung called on the government to reflect on measures that would enable Koreans from China and Russia to enjoy the same rights as Koreans from other countries ${ }^{63}$. On 10 July 2001, following a report by several NGOs condemning the discrimination and ill-treatment inflicted on some Chinese Koreans in South Korea, the justice minister promised to "humanise" his policy towards them and also to crack down on groups or individuals who exploit them ${ }^{(64)}$. In the end, on 29 November 2001, South Korea's Constitutional Court ruled the 1999 law to be in breach of the constitution and ordered that it be revised by the end of 2003 65 .

Despite this apparent change of heart, the policy of the South Korean authorities towards Korean immigrants from China has alternated between firmness and kindness since the start of 2002. Numerous anecdotes concerning the illegal entry of Koreans 
from China before, during and after the staging of the football World Cup in May 2002 have convinced the government to strengthen its controls on immigration and to prepare strict measures to tackle the problem of illegal workers ${ }^{66}$. At the same time, it has authorised Koreans from China to work in the service sector, enabling them to apply for visas valid for at least two years ${ }^{67}$. This fluctuation in South Korean policy is the consequence of numerous pressures on the central South Korean government on two fronts. On the one hand, it has to avoid any friction with the Chinese government. On the other, it must respond to the expectations of Chaoxianzu immigrants and of the South Korean NGOs, expectations that were demonstrated afresh in January 2003 when the NGOs opposed the government's decision to send some immigrants back to China ${ }^{68}$.

For its part, the Chinese government criticises any decision to treat the Chaoxianzu like any other expatriate Koreans. In its eyes, the Chaoxianzu are-and always will beChinese citizens of Korean origin. It would prefer Seoul's law discriminating against Chinese Koreans to be kept in force because it helps to encourage their loyalty to the People's Republic. Thus, because it gave citizen's rights to some Korean expatriates on the basis of their ethnicity, the Chinese government castigated the 1999 law. Now, however, judging that if Seoul eventually widens the law to include Chinese Koreans this will be in defiance of Chinese sovereignty, Peking is sharply opposed to its revision. This opposition is all the stronger in that the discourse surrounding notions of citizenship, ethnicity and sovereignty is taken up by some extreme right-wing fringe groups in South Korea who claim Yanbian as Korean territory. To show its displeasure, Peking twice refused, early in 2002, to issue Chinese visas to South Korean jurists responsible for visiting Chinese Koreans for talks about the revision of the 1999 law ${ }^{69}$.

This was not the first time that the Chinese government had refused entry to South Koreans. It had already prevented delegates from South Korean NGOs from going to Yanbian to provide aid for the refugees from North Korea.

Aid for North Korean refugees: a Chaoxianzu-Korean connection that annoys Peking

The Chaoxianzu are not the only people helping the North Korean refugees. A few South Korean NGOs and NGOs set-up by Koreans from abroad (mainly American Koreans), settled in Yanbian, also regularly come to the aid of the refugees. Alongside the Chaoxianzu, these NGOs have even played an important role in transporting North Korean refugees to foreign embassies in Peking ${ }^{70}$. While the central government tolerated, until recent months, the presence of these NGOs-as long as they remained discreet-it considers their participation in organising expeditions to the embassies to be in violation of Chinese sovereignty. As these NGOs have also deeply embarrassed the Chinese government in its relations with North and South Korea, it has responded immediately by cracking down not only on the refugees but also on their accomplices ${ }^{71}$. Furthermore, while the repression of the Chaoxianzu is an internal matter for the Chinese, the crackdown on the South Korean NGOs is closely watched by the Seoul authorities-the more so in that some of the NGOs (many being religious in character) are also playing a leading part in defending the Chaoxianzu in South Korea. Some active members of the Christian NGOs were thus arrested by the Chinese police who accused them of proselytising, which is forbidden in China ${ }^{72}$. However, being anxious not to get into a row with Seoul, the Chinese authorities imposed limited penalties, in most cases freeing them after they had paid heavy fines. These diplomatic limitations explain why Peking is also attempting to obstruct the work of these NGOs at an earlier stage by preventing them from coming to China. A black list naming some of their leaders has 
been sent to the Chinese embassy in South Korea, which is ordered not to issue any more visas to them ${ }^{73}$.

The emergence of an illegal traffic in refugees

As many Chinese (including Chaoxianzu) as Koreans from the peninsular are involved in the criminal network, which is a growing presence in the region. The transporting of Chaoxianzu to South Korea is accompanied, for example, by a significant traffic in South Korean passports, forged marriage certificates and work permits. It is more and more common for South Koreans in Yanbian and the Chinese Northeast to find that their passports have been stolen or unfortunately misplaced. As for forged marriage certificates, these can also have two uses: some of them can be used to create a marriage between a Chaoxianzu man and a woman refugee from North Korea. Most of the time, these arranged marriages are in fact forced marriages. The criminal gangs quickly understood how to benefit from the situation and they have put in place a significant network for smuggling women whom they sell to the peasants in Yanbian or elsewhere. Those who are not sold are switched into the region's many prostitution networks. Lastly, in addition to being a centre for the traffic in women, Yanbian is also an important transit area for drugs coming in from North Korea, most of which are eventually sold in South Korea ${ }^{74}$.

While the Chinese and South Korean governments have agreed to co-operate in dismantling the various trafficking networks, some differences persist over the best methods to adopt.

In October 2001, the Chinese authorities executed a smuggler of South Korean origin without informing the South Korean diplomatic mission in China. The government of South Korea protested sharply over this act, which thus created a new diplomatic incident. The problem was finally resolved during a meeting of the two countries' foreign ministers on 4 November $20011^{75}$.

A much-needed new start for development: xibu dakaifa to the rescue of Tumen?

The numerous connections maintained by the Chaoxianzu with the South Korean NGOs and the North Korean refugees led to the organisation of the sanguan jiaoyu campaign during the spring and summer of $2002{ }^{76}$. Indeed, even though Chinese studies show that the majority of the Yanbian Koreans still consider themselves Chinese, the researchers emphasise the need to strengthen their patriotism and their sense of cohesion with other nationalities (that is with the Han) by improving education ${ }^{77}$. However, the Chinese government is aware that mere educational reforms will not be enough to resolve the problems. It has recently been attempting to relaunch economic development in the prefecture. Thus, after setting up a processing and export zone (chukou jiagong qu) in Hunchun, in April $2000{ }^{(78)}$ ), on 8 March 2001 the State Council authorised the Yanbian prefecture to receive the benefits of the policy of the "Great Opening Up of the West" (xibu dakaifa) ${ }^{79}$. This decision was prompted, above all, by growing pressure from the Yanbian authorities (passed on doubtless by those of Jilin province) who, confronted with the failure of the Tumen programme, wished to relaunch Yanbian's development ${ }^{80}$. Although the prefecture is situated on the edge of the Northeast, the authorities maintained that Yanbian was an old, poor administrative frontier entity inhabited by national minorities and could, given these characteristics, benefit just as much from this policy as the other autonomous prefectures located in the western provinces ${ }^{81}$. So since March 2001 Yanbian has been receiving new state subsidies and a more advantageous fiscal regime which ought to enable it to attract 
more foreign investment across a greater number of sectors and to profit a little more from its own fiscal resources. It is also authorised to adopt a few measures to protect the environment and to develop scientific and technical education as well as zones of economic and technological co-operation. Lastly, Yanbian has been offered new prerogatives in promoting tourism and frontier trade.

During the year 2001, Yanbian received 550 million yuan (66.3 million US dollars) in central government. Between 2003 and 2008, the authorities, both central and regional, are committed to making available 4 billion yuan (481 million dollars) for developing infrastructure and certain key industrial projects which were not completed at the time of the first phase of the Tumen programme ${ }^{82}$. As regards foreign investment, the Yanbian authorities have also taken advantage of the fiftieth anniversary to organise an investment forum in Yanji. It opened from 2 to 4 September 2002 and welcomed 2,270 potential investors from 12 countries. In all, 254 investment projects worth a total of 1,165 billion dollars, as well as a large number of commercial contracts worth 743 million dollars, were signed ${ }^{83}$.

The renewed commitment of the central government to developing Yanbian is, as was the case in the early 1980s, closely linked to the state of its relations with and strategy towards the two Koreas. Only a few weeks before the two Korean heads of state met for the Pyongyang summit in June 2000, Kim Jong-Il had paid a secret visit to Peking where he was closeted with the senior CCP leaders ${ }^{84}$. On a second visit to China, during January 2001, he also went to Shanghai ${ }^{85}$. Lastly, in September 2001, Jiang Zemin visited Pyongyang for the first time in ten years, which, after all the tensions of the second half of the 1990s, thus symbolised the restoration of good relations between the two countries ${ }^{86}$. In addition to strategic questions (including TMD, NMD and the presence of American troops in South Korea), these meetings also provided an opportunity for the two governments to discuss economic development. Kim Jong-Il having praised to the skies the successes of the Chinese reforms, it is not surprising that, following these meetings, the North Korean regime adopted numerous openness measures between 2000 and autumn 2002.

Justifiably impressed by the many political and economic advances that were made in the two Koreas during this period, South Korea's political and economic leaders are again showing great interest in the Tumen programme, in particular in its potential role in opening up North Korea and its importance in connecting up the transport networks between China and the two Koreas and between the two Koreas themselves. The Federation of South Korean Industries, encouraged by Seoul and having strengthened its links with its Chinese counterpart in February 2001, declared on 22 March 2001 its intention of taking an active part in the development of the Tumen region. ${ }^{87}$.

China's closer links with North Korea have since been overshadowed by a second nuclear crisis, which attests once again to the volatile, unpredictable and above all dangerous behaviour of the North Korean regime as well as to the complexity of the Peking-Pyongyang relationship. Annoyed by this behaviour, the Chinese government has taken political and strategic measures that have directly affected Yanbian. For example, Peking has told all North Korean officials-those who had been allowed to stay in the prefecture to hunt down refugees-to return home ${ }^{88}$.

While it is too soon to analyse what the relaunch of the Tumen development will lead to, it is clear that its success will depend not just on resolving this second nuclear crisis 
but also and more particularly on overcoming Yanbian's present economic problems (skills shortage, problematic restructuring of state enterprises, inadequate foreign investment and low levels of cross-border trade) ${ }^{89}$. The task ahead appears all the more arduous in that China's recent accession to the World Trade Organisation is likely to cause new difficulties for the prefecture, particularly in agriculture-which still accounts for $16 \%$ of Yanbian's GDP-and the many state enterprises ${ }^{90}$. Lastly, the Tumen development cannot go ahead without a significant inflow of foreign investment, especially from South Korea.

61 We shall also have to watch closely what impact the relaunch of the development will have on the changing identity of the Chaoxianzu. That most Yanbian Koreans still feel themselves to be Chinese can largely be attributed to the disillusionment that many have felt in South Korea. The geopolitical importance of the Korean minority depends above all on China's relations with the peninsular. From this perspective, because of the reactions it will provoke within the Chinese government and among the Chaoxianzu, the revision of the South Korean law affecting Koreans from abroad will without any doubt mark a critical stage in the relationship between the two countries. It will also represent a basic gauge of the prospects for Korean reunification. Even though it is hard to foresee what form the new Korean discourse on the frontier and on China's Korean minority will take, it is likely that the influence exerted by a reunified Korea on Yanbian and its Koreans will again be enormous. While one cannot put aside the possibility of destabilising influences ${ }^{\left({ }^{11}\right)}$, reunification-and, of course, before that, the opening up of North Korea-could have a very positive effect on economic development, both for Yanbian and for all of China's Koreans. In view of its frontier position, the Yanbian prefecture could then become Korea's back door into China and thus profit by its geographical situation in the heart of Northeast Asia. However, this success will also depend on what strategic perceptions Chinese leaders will then have of the peninsular, for these still govern their policy towards Yanbian and the Korean minority.

In my work on Chinese frontier policy in Northeast Asia, I studied at the Teaching University of Northeast Changchun (Jilin) from September 2000 to July 2001 and travelled several times to the Yanbian Korean Autonomous Prefecture (thanks to a grant from France's Ministry of Foreign Affairs). I should like to thank the CEFC for financing my most recent visits to Yanbian and South Korea during the summer of 2002. I also thank all those who gave me their comments on earlier versions of this article.

\section{NOTES}

1.The People's Republic of China is home to $2,188,000$ Koreans, $97 \%$ of whom live in the three provinces of the Northeast (Jilin: 61\%; Heilongjiang: 23\%; Liaoning: 12\%). In Jilin, apart from the Autonomous Prefecture of Yanbian, the Koreans are also strongly represented in the autonomous county of Changbai (home to $16 \%$ of the nationwide 
Korean population) as well as eleven villages, of which five are Korean-Manchu, and one town. In Heilongjiang and Liaoning, the Korean minority lives mainly in villages (26) and towns (10). For more details on the distribution of the Korean minority in China, cf. Zhu Zaixian, "Dui Zhongguo Chaoxianzu renkou fenbu yu tedian jiqi fazhan qushi de fenxi" (Analysis of the distribution of the population and of the characteristics of China's Korean minority as well as of development prospects), in Chaoxianzu yanjiu luncong (research series on the Korean minority), Vol. 5, edited by the Research Centre on Nationalities of Yanbian University, Yanji, Yanbian daxue chubanshe, 2001, pp. 223-249.

2.The other autonomous prefectures are located in other regions of China in the west, the southwest and the south, mainly in the provinces of Yunnan, Sichuan, Guizhou and Gansu, and in the five autonomous regions.

3.To describe it, Chinese specialists on nationalities use the phrases qianru minzu (immigrant nationality) and kuajing minzu (transnational nationality). Interviews, Yanji, May 2001.

4.During our stay in Yanbian in August 2002, one month before the festivities began, numerous slogans were displayed proclaiming the need for economic development. For more details on the Yanbian anniversary, cf. Zhao Yang, "50th Anniversary of Founding of Yanbian's Korean Autonomous Prefecture", China Radio International, September 2002, http://english.cri.com.cn/english/2002/sep/69718.htm

5.Each September in Yanbian is the month selected for the broadcasting of propaganda about the union of nationalities (minzu tuanjie xuanchuan yue). It is always timed to coincide with the celebration of the anniversary of the founding of Yanbian as an autonomous administrative entity for national minorities. Xu Mingzhe, Dangdai yanbian Chaoxianzu shehui fazhan duice fenxi (Analyses and counter-measures of the development of society among the Yanbian Koreans today) Shenyang, Liaoning minzu chubanshe, 2001, p. 363.

6.Sanguan jiaoyu is an education movement organised by the central government and the provincial authorities whenever the latter judge that unity between the nationalities is in danger, whether because tension arises between the Han and the minorities or because the minority or the minorities step outside certain guidelines laid down by the authorities. This type of campaign is invariably aimed at the national minorities and is always carried out in minority areas (provinces, prefectures or counties). As its name suggests, the sanguan jiaoyu is the teaching of the three guan (which we may translate as idea, concept or conception). These three concepts are zhuguoguan ( $\mathrm{zhu}$ = to reside, guo = country, namely China; no one should forget that the national minorities reside in the country, that is to say in China), minzuguan (no one should forget that these are nationalities of China, a multinational state and that they enjoy certain privileges at the political, economic and social level) and lishiguan (lishi= history; no one should forget that historically the minorities are part of China and that they have participated in the founding of this multinational state). The exact definition of the three concepts is a little vague; the few researchers who refer to them also give no precise definitions. To sum up, the sanguan jiaoyu is a campaign aimed at making the national minorities aware that the country, the state and China are more important than their nationality and that, while the specific nationality is respected (from the perspective of the centre), the national minorities must not set it above the state. Interviews, Yanji, 1 and 3 August 2002; Xu Mingzhe, op. cit., 2001, pp. 384-385. The sanguan jiaoyu campaign was relaunched in spring 2003 in Yanbian. The intention is 
preventive; the campaign is directly connected with the revision of the South Korean law on Koreans from abroad, which is to take place between now and the end of 2003. 7.Yanbian chaoxianzu zizhizhou zhi (Records of the Autonomous Prefecture of the Yanbian Koreans), Peking, Zhonghua shuju, 1996, pp. 253-354; Bruno Lasker, Les peuples de l'Asie en mouvement, Paris, Payot, 1946, p. 100.

8.We are concerned here with the treaties of Aïgoun and Peking. The treaty of Aïgoun, signed on 16 May 1858, placed the frontier between China and Russia along the River Amour, the areas lying to the south of the Amour and between the River Oussouri and the sea under Chinese and Russian dual jurisdiction. Two years later, the Peking treaty permanently transferred these territories to Russia, which meant China lost its access to the sea.

9.With the exception of the few Korean Catholics fleeing from state persecution in the Korean kingdom in the 1860 s and 1870s, the main cause of this Korean emigration was economic.

10.For more detailed information about Russian and Japanese influences, cf. in particular André Fabre, Histoire de la Corée, Paris, l'Asiathèque, 2000, 419 p.

11.For more details on the issue of Korean migration between China, Korea and Japan, cf. Larisa V. Zabrovskaïa, "Consequences of Korean Emigration to Jiandao", Korea Journal, spring, 1993, pp. 69-77. Jiandao is the old name for the present-day Yanbian prefecture.

12.Zhonghua renmin gongheguo diming cidian, (Dictionary of Geographical Names of the People's Republic of China), volume on Jilin, Peking, Shangwu yinshuguan, 1994, pp. 252-253.

13. Mao Yuanxin lived in Harbin in a province of Heilongjiang. His arrival in Yanbian in August 1967 coincided with a radicalisation of the Cultural Revolution, and it was from this period onwards that a real policy of assimilation was launched against Yanbian's Korean minority. Mao Yuanxin was not officially posted to Yanbian, but he arrived there at the time martial law was declared and all power passed into the hands of the People's Liberation Army (PLA). The political situation in the prefecture was chaotic at that time because of the battles that had been raging between the PLA, various factions of Red Guards and members of the Korean minority. On his arrival, Mao Yuanxin declared that the leftist groups were not radical enough and proposed more actively to attack the Korean minority and its leaders; he founded a group called "red group" whose aim was to "liberate Yanbian", defined as a kingdom in the hands of a few local Chaoxianzu. Actively supported by the PLA, Mao Yuanxin and his group quickly established themselves as the leaders of the prefecture. Why Mao Yuanxin went to stay in the Yanbian Korean Autonomous Prefecture is very unclear; even a specialist on that period, Lee Jeanyong, admits that he does not know the reason. It is very likely, however, that Mao Yuanxin came there on the orders of his uncle, Mao Zedong. While asking his forces to attack the Korean minority, Mao Yuanxin had a particular target in mind: Zhu Dehai, who had been governor of the prefecture since its foundation. Zhu Dehai was very close to Zhou Enlai and had acquired great power during the 1950s and 1960s. Along with Zhou, he had been party to the negotiations setting out the frontier with North Korea and had been an important element in defining China's foreign policy towards North Korea. During the Cultural Revolution, Zhu Dehai was even accused of being a spy in the pay of North Korea. The attack upon him now was undoubtedly connected with the state of China's relations with North Korea, which became very hostile at precisely this period. It may be that Mao had become suspicious of Zhu Dehai 
and asked his nephew to take a hand. Perhaps he could not do it directly because of Zhou's support for Zhu Dehai. For detailed analyses of these times, cf. Bernard-Vincent Olivier, The Implementation of China's Nationality Policy in the Northeastern Provinces, San Francisco, Mellen Research University Press, 1993, 283 pages; Lee Jeanyong, "Integration to the Chinese Society: Korean minority in China during the Campaign Period (1957-1978)", Journal of Asia Pacific Affairs, Vol. 3, 2001, pp. 1-26.

14.Xu Mingzhe, op. cit., 2001, p. 364; Yanbian chaoxianzu zizhizhou zhi, op. cit., 1996, p. 345.

15.Li Delong ed., Jianshe mofan zizhizhou (Setting up a model prefecture), Changchun, Jilin renmin chubanshe, 1991, p. 3.

16.Park Kyung-Ae, "China's Korean Policy and the Role of the Korean-Chinese in InterKorean Relations", Korean Observer, Vol. XXII, No. 2, summer 1991, pp. 207-228.

17.For detailed studies on the Tumen project and what it represented for the Chinese authorities, cf. James Cotton, "China and Tumen River Cooperation: Jilin's Coastal Development Strategy”, Asian Survey, Vol. XXXVI, No. 11, November, 1996, pp. 1086-1099; Jean-Marc Blanchard, "The Heyday of Beijing's Participation in the Tumen River Area Development Program, 1990-1995: A Political Explanation”, Journal of Contemporary China, Vol. 9, No. 24, 2000, pp. 271-290; Sébastien Colin, “Ambitieuse tentative de coopération en Asie du Nord-Est: la zone de développement économique du fleuve Tumen", Hérodote, No. 97, 2nd Term, 2000, pp. 88-106; Sébastien Colin, "Difficile émergence d'une coopération régionale en Asie du Nord-Est: progrès, problèmes et enjeux du programme Tumen", in Philippe Pelletier et Christian Taillard, eds., Asie orientale: intégration régionale, (appearing shortly).

18.Between 1980 and 1990, the value of Yanbian's industrial production rose from 995 million to 4,2 billion yuan, representing average annual growth of $9,92 \%$. However, this rapid growth was matched by the economic development taking place elsewhere in the country, and the relative gaps in development were never closed. Over the same period, Yanbian's growth rate was in fact similar to the provincial and national rates, but much lower than the growth rates in the coastal provinces. Cui Jinshu, "Yanbian jingii fazhan de xiankuang wenti ji silu" (Situation and problems of Yanbian's economic development and suggestions), Yanbian daxue xuebao (shehui kexue ban), Vol. 33, No. 3, pp. 15-17.

19.Li Delong ed., op. cit., 1991, p. 3.

20.Outi Luova, "The use of ethnicity in local economic development: the case of Koreans in the Yanbian Korean Autonomous Prefecture, Jilin Province", Provincial China, No. 6, April 1999, p. 23.

21.In 1979, twinning relationships were established between places in China and North Korea: Hunchun with Saebyôl, Tumen with Onsong, Longjing with Hoeryông and Helong with Musan. In April 1984, the Yanbian Korean Autonomous Prefecture was twinned with the North Korean municipality of Chôngjin. Yanbian chaoxianzu zizhizhou zhi, op. cit., 1996, p. 501.

22.The Sino-North Korean agreement on opening the border (bianjing jumin guojing tongxing zheng) was signed in 1955. It allows frontier populations to go and visit their families on the other side of the frontier. For a résumé of that agreement, cf. Yanbian chaoxianzu zizhizhou zhi, op. cit., 1996, pp. 545-547. For the complete text of the agreement, cf. Zhongchao liangguo bianjing jumin guojing tongxingzheng fafang he guanli banfa (Modalities allocating and managing the frontier passes for frontier residents of 
the People's Republic of China and of the People's Democratic Republic of Korea), 6 June 1955.

23.Lim Kûm-Suk, "Yônbyôn kwa josôn byôngyông jiyôkganûi gyôngje muyôk kyoryu hyôn hwangkwa jônmang" (Situation and prospects of commercial, economic and educational exchanges between the frontier regions of Yanbian and North Korea), in Kim Kang-Il, ed., Jungguk josônjok sahwoeûi munhwausu wa baljôn jônryak, (Strategy for development and cultural values of the Chaoxianzu society of China), Yanji, Yônbyôn inmin ch'ulbansa, 2001, pp. 377-378 (in Korean); Yanbian tongji nianjian 2000, (Yanbian Statistical Yearbook, 2000), Yanji, Yanbian renmin chubanshe, 2001, p. 282.

24.We are concerned here with the Dunhua, Antu and Tumen zones created in August 1992 and the Yanji zone created in May 1995. Cf. Pu Chengxian, "Tumenjiang diqu kaifa yu yanbian jingji" (The Tumen River Economic Development Zone and the Economy of Yanbian), in Chaoxianzu yanjiu luncong, op. cit., 2001, pp. 305-307.

25.Interviews, Yanji and Changchun, 2001. There are about forty Yanbian enterprises in the Rajin-Sonbong zone. With the exception of the Xiantong group and the Longxing Trading Company, most are small businesses, restaurants or travel agencies.

26.Xu Mingzhe, op. cit., 2001, p. 376.

27.By way of comparison, direct foreign investment in Jilin during the year 2000 amounted to about 596 million dollars. Jilin tongji nianjian 2001 (Jilin Statistical Yearbook, 2001), Peking, Zhongguo tongji chubanshe, 2001, p. 351.

28.Pu Chengxian, Yanbian jingji xingshi fenxi yu yuce (Analyses and Forecasts of Yanbian's Economic Situation), Yanji, Yanbian daxue chubanshe, 2001, pp. 80-85. 29.Outi Luova, op. cit., 1999, p. 24 and p. 31; interviews, Yanji, June 2001.

30.Pu Chengxian, op. cit., 2001, p. 85.

31.The value of frontier trade with North Korea in 2000 scarcely reached that of 1989.

32.The minying qiye are private enterprises that bring together capital from one or more individuals, traders or others. In 2000, 20\% of the trade between Yanbian and Russia and almost all the trade between Yanbian and North Korea were provided by these minying qiye. As for the frontier trade with North Korea, most of the traders take advantage of the open border between the two countries to go to the handful of the free open markets in the North Korean frontier districts. The Yanbian prefecture has a frontier crossing into Russia and seven into North Korea; in that order, they are Changlingzi (Hunchun), Tumen, Shatuozi, Quanhe, Nanping, Changshenzhen (Guchengli), Sanhe and Kaishantun (cf. map). Interviews and observations during a visit to Yanbian, August 2002.

33.In 2000, the value of Sino-Russian trade through Heihe and Suifenhe reached 1.47 and 10.1 billion dollars respectively, and, by itself, Suifenhe was the crossing point for $12.5 \%$ of Sino-Russian frontier trade. Located to the south of Liaoning, the Dandong frontier post is the crossing point for $60 \%$ of Sino-North Korean trade as against only $24 \%$ for Yanbian, even though the latter has seven frontier posts along its North Korean border.

34.For more details on the problems of the Tumen programme, cf. Sébastien Colin, op. cit., (appearing shortly).

35.Between 1991 and 2000, ten billion yuan were invested by China's central and provincial authorities. According to some sources, this sum was far too little to drive the prefecture's development through to a successful conclusion. Interviews, February and June 2001.

36.James Cotton, op. cit., 1996, pp. 1096-1098; interviews, Yanji, February 2001. 
37.For detailed analyses on how the double identity of the Chaoxianzu was formed, cf. Choi Woo-Gill, "The Korean Minority in China: the Change of its Identity", Development and Society, Vol. 30, No. 1, June 2001, pp. 119-141; Park Han-Shik, "Political Culture and Ideology of the Korean Minority in China", Korean Studies, Vol. 11, 1987, pp. 13-32; Bernard-Vincent Olivier, "Les fluctuations de l'identité des Coréens de Chine", in Yim Seong-Sook. ed., La Corée, le peuple et ses valeurs culturelles d'hier à aujourd'hui, Montréal, Les presses de l'Université de Montréal, 2000, pp. 125-138.

38.Interviews, Yanji, June 2001.

39. According to Outi Luova, the Yanbian Koreans were unable to adapt to the reforms for three reasons. Firstly, they were too attached to their traditional cultivation of rice and were reluctant to commit themselves to other activities. Secondly, being faithful to their Confucian culture, they considered it improper to engage in trade. Lastly, having benefited greatly from the socialist system, they did not want to leave it in order to expose themselves to the intense and uncertain competition of the market. Outi Luova, op. cit., 1999, p. 19.

40.Shen Wangen, Tan Yujie, "Shilun yanbian chengzhen pinkun renkou de fenbu tezheng" (Essay on how urban poverty in Yanbian is distributed), Yanbian daxue xuebao (shehui kexue ban), Vol. 35, No. 1, March 2002, pp. 34-37; interviews, June 2001. 41.Pu Minzi, "Qiantan chaoxianzu renkou fazhan zhong de jige wenti” (Short discussion of a few problems relating to the population of Korean nationality), in Chaoxianzu yanjiu luncong, op. cit., 2001, pp. 250-255.

42. Outi Luova, "Chinese Korean Labour Migration to South Korea: Changing Ethnic and National Identities", June 2002, an article that is available on the Internet at http:// www.iisg.nl/\%7Eclara/clarawp.htm.

43.Outi Luova, op. cit., 2002.

44.Renmin Ribao, 29 August 2002, online edition (English version) at http:// english.peopledaily.com.cn/20020829/print20020829_102266.html.

45.Interviews, Yanji, June 2001; Pu Minzi, op. cit., 2001, pp. 250-255.

46.For a comparison of the figures, cf. White Paper on Human Rights in North Korea, 2001, Korea Institute for National Unification, pp. 120-121.

47.Interviews, Yanji, August 2002.

48.About $85 \%$ of the North Korean refugees are said to be married to Chinese peasants. Interview, Yanji, August 2002.

49. Choi Woo-Gill, op. cit., 2001, pp. 137-138. Interviews, Seoul and Yanji, August 2002.

50.Xu Mingzhe, op. cit., 2001, p. 371.

51.Ibid., 2001, p. 371.

52.In 2001, the percentage of Korean officials was 3.9 points above that of the population.

53.Wang Dongyang, Jin Guangshi, "Yanbian chaoxianzu renkou xiankuang ji renkou fazhan zhanlüe" (Present situation of the Korean population of Yanbian and its development strategy), Yanbian daxue xuebao (shehui kexue ban), Vol. 33, No. 1, February, 2000, pp. 76-79.

54.Outi Luova, op. cit., 2002; Xu Mingzhe, op. cit., 2001, pp. 378-379; Choi Woo-Gill, op. cit., 2001, p. 139.

55.In 1996, only $60 \%$ of young Chinese Koreans living in the big cities spoke Korean. Choi Woo-Gill, op. cit., 2001, p. 126.

56.Park Han-Shik, op. cit., 1987, pp. 25-28; Choi Woo-Gill, op. cit., 2001, p. 131. 
57.For more on the disillusionment of the Chaoxianzu in South Korea, cf. BernardVincent Olivier, op. cit., 2000; Outi Luova, op. cit., 2002.

58. Manduertu, Zhongguo shaoshu minzu xianzhuang yu fazhan diaocha yanjiu congshu, Chaoxianzu juan, Longjing shi (Series of studies and surveys relating to the situation and development of China's national minorities, volume on the Korean minority, municipality of Longjing), Peking, Minzu chubanshe, 1999, p. 287.

59.In 1998, 70\% of China's Koreans considered China to be their country. Choi Woo-Gill, op. cit., 2001, p. 139.

60.Xu Mingzhe, op. cit., 2001, p. 364; Yanbian chaoxianzu zizhizhou zhi, op. cit., 1996, p. 345. According to Liu Zanwen, this situation is valid in all the Korean autonomous administrative entities in the Northeast. Cf. Liu Zanwen, "Zhongguo dongbei chaoxianzu zizhi difang minzu hemu de chengyin chutan" (Early research into the origin of harmony between nationalities in the autonomous zones of the Koreans of Northeast China), Heilongjiang minzu congkan, No. 2, 2001, pp. 23-28.

61.Interviews, Yanji, Changchun and Peking, 2001.

62.Scott Snyder, "Focus on Stability Despite New Challenges", Comparative connections, Vol. 1, July-September 1999. (Review accessible online at http://www.csis.org).

63.Ibid.

64.Scott Snyder, "Navigating the Swiftly Shifting Currents", Comparative Connections, Vol. 3, July-September 2001.

65.Scott Snyder, "Keeping the Eye on the (WTO) Prize While Containing Consular Crises", Comparative Connections, Vol. 3, October-December 2001.

66.For a detailed list of these anecdotes, cf. Scott Snyder, "Transit, Traffic Control, and Telecoms: Crossing the "T's" in Sino-Korean Exchange", Comparative Connections, Vol. 4, January-March 2002.

67.Scott Snyder, “Beijing in the Driver's Seat? China's Rising Influence on the Two Koreas", Comparative Connections, Vol. 4, October-December 2002.

68. Chosun Ilbo, 10 and 28 January 2003, English-language editions available online at http://english.chosun.com.

69.Scott Snyder, op. cit., Vol. 4, January-March 2002.

70.Interviews, Peking, August 2002.

71.Chosun Ilbo (online editions), 9 June and 14 November 2002.

72. While this accusation is mainly a pretext for the arrests, one cannot deny the fact that some NGOs attempt to convert a few souls in exchange for their help. This religious influence generally only affects North Korean refugees, but also some Chaoxianzu, which embarrasses the central government: it sees in it a challenge to its own political control.

73.Scott Snyder, “Happy Tenth for PRC-ROK Relations! Celebrate While You Can, Because Tough Times are Ahead", Comparative Connections, Vol. 4, July-September 2002. 74.Interviews, Seoul and Yanji, August 2002.

75.Scott Snyder, op. cit., Vol. 3, October-December 2001.

76.Interview, Yanji, 3 August 2002.

77.Among these studies, cf. Quan Guoquan, Yu tian, "Dui zhongguo chaoxianzu shengcun yu fazhan wenti de shiji sikao" (Reflections on the problems of existence and development of China's Koreans), Yanbian daxue xuebao (shehui kexue ban), Vol. 32, No. 4, November, 1999, pp. 93-98; Piao Jinhai, Zheng Xinzhe, “Lüelun zhongguo chaoxianzu de aiguozhuyi qingjie" (Brief viewpoint on the patriotic feelings of China's 
Koreans), Zhongyang minzu daxue xuebao, No. 4, 2000, pp. 6-12; Liu Zanwen, op. cit., 2001, pp. 23-28.

78.Apart from Hunchun, fourteen other chukou jiagong qu have been created in Dalian, Tianjin, Peking, Tianzu, Yantai, Weihai, Kunshan, Suzhou, Shanghai, Songjiang, Hangzhou, Xiamen, Xinglin, Shenzhen, Guangzhou, Wuhan and Chengdu. Among these fifteen zones, only those of Hunchun, Wuhan and Chengdu are not located along China's coast. For more information about these zones, cf. Tsukada Hiroyuki, "The Export Processing Zone: Its Current Situation and Prospects", China Newsletter, Jetro, Vol. 6, No. 149, 2000, pp. 2-14.

79.Pu Chengxian, op. cit., 2001, p. 75; Fang Min, “Guanyu Tumenjiang diqu kaifang kaifa gongzuo qingkuang de baogao" (Report on the Tumen River Economic Development Zone: the situation and the activity of opening it up and developing it), July 17th 2002, (unpublished report), p. 2. Fang Min is the Director of the Development Bureau of the Tumen River Economic Development Zone of the province of Jilin.

80.Interviews, Yanji, February and June 2001.

81.Interviews, Yanji, February and June 2001.

82.Cf. online editions of Renmin Ribao, 19 March 2002 (http://

english.peopledaily.com.cn/200203/19/print20020319_92371.html) and 6 August 2002

(http://english.peopledaily.com.cn/200208/06/print20020806_100983.html).

83.Tumen Secretariat, online document at http://www.tumenprogramme.org/tumen/ news/YanjiInvest Forum.

84.Scott Snyder, "Beijing at Center Stage or Upstaged By the Two Kims?", Comparative Connections, Vol. 2, April-June 2000.

85.Scott Snyder, “The Winds of Change: Fresh Air or Pollution?”, Comparative Connections, Vol. 3, January-March 2001.

86.Scott Snyder, op. cit., Comparative Connections, Vol. 3, July-September 2001.

87.Scott Snyder, op. cit., Vol. 3, January-March 2001.

88.Wang Jianmin, Mao Feng, "Zhongchao die dui die hupo qingbaowang" (China and North Korea spy on each other and suppress their network of mutual information), Yazhou zhoukan, 27 January - 2 February, 2003, p. 4.

89.Piao Changjie, "Yanbian zai canyu xibu dakaifa zhanlüe zhong ying zhua hao de jige wenti" (The few problems that Yanbian will have to confront while participating in the development strategy of the Great West), Yanbian daxue xuebao (shehui kexue ban), Vol. 35, No. 2, June, 2002, pp. 33-37.

90.Xuan Dongri, An Yuhua, “Zhongguo jiaru WTO dui yanbian jingji de yingxiang jiqi duice tantao" (The infuence of China's accession to the WTO on Yanbian's economy, counter-measures and discussions), Yanbian daxue xuebao (shehui kexue ban), Vol. 33, No. 3, August, 2000, pp. 1-4; Long Yongtu, “The Tumen Region and the Impact of China's Accession to WTO", Tumen update, No. 5, May, 2002, p. 4 and 5. Long Yongtu is the Deputy Minister for External Trade and Economic Co-operation and was the head of the Chinese delegation in the negotiations leading up to China's entry to the WTO.

91.These destabilising influences would arise only if reunification happens violently and drives many Koreans to flee into the Yanbian prefecture and elsewhere in China. In the case of a gradual and peaceful reunification, the destabilising factors would be linked only to a general emigration of Yanbian Koreans towards South Korea or to South Korean political claims. Apart from a few isolated speeches coming from small extreme right-wing groupings, no political claims to Yanbian are being made in South Korea. 